\title{
The first record of Libellula depressa Linnaeus, 1758 (Odonata: Libellulidae) in Siberia, Russia
}

\author{
Oleg E. Kosterin ${ }^{1,2}$, Alexey V. Gribkov ${ }^{3}$ \\ ${ }^{1}$ Institute of Cytology \& Genetics, Siberian Branch of Russian Academy of Science \\ Acad. Lavrentyev Ave 10, Novosibirsk, 630090, Russia \\ ${ }^{2}$ Novosibirsk State University \\ Pirogova St. 2, Novosibirsk,630090,Russia,Email:kosterin@bionet.nsc.ru \\ ${ }^{3}$ Tigireksky Nature Reserve \\ Nikitina St.111, Barnaul,656043, Russia,Email: gribkov2005@list.ru
}

Libellula depressa (Linnaeus, 1758) was recorded from the NW foothills of Altai Mts. at the Inya River near the Chineta Village $\left(51.34^{\circ} \mathrm{N}, 83.05^{\circ} \mathrm{E}\right)$ in Kranoshchekovo District of Altayskiy Kray Province, Russia. This record was made for the first time in the territory of Russia, eastward of Urals and in $150 \mathrm{~km}$ NNE of the closest locality in East Kazakhstan in Ust'-Kamenogorsk (Oskemen).

Keywords: Odonata; dragonflies; Libellula depressa; Siberia; first record

Libellula depressa Linnaeus, 1758 is a dragonfly species common in Europe, Anterior Asia and Kazakhstan (Kalkman, Chelmik, 2015; Chaplina et. al., 2007) but hitherto unknown in the Russian territory east of Ural. Belyshev (1973) included it into his monograph 'Dragonflies of Siberia' because of the report from Bol'shenarymskoe Village, which is situated in the West Altai in the territory of Kazakhstan, East Kazakhstan Province. In the Kazakhstan part of Altai, L. depressa is also known from Ust'-Kamenogorsk (Oskemen) City (Chaplina et al., 2007; data of the first author - see Fig. 1) and Zaisan Town (Chaplina et. al., 2007).

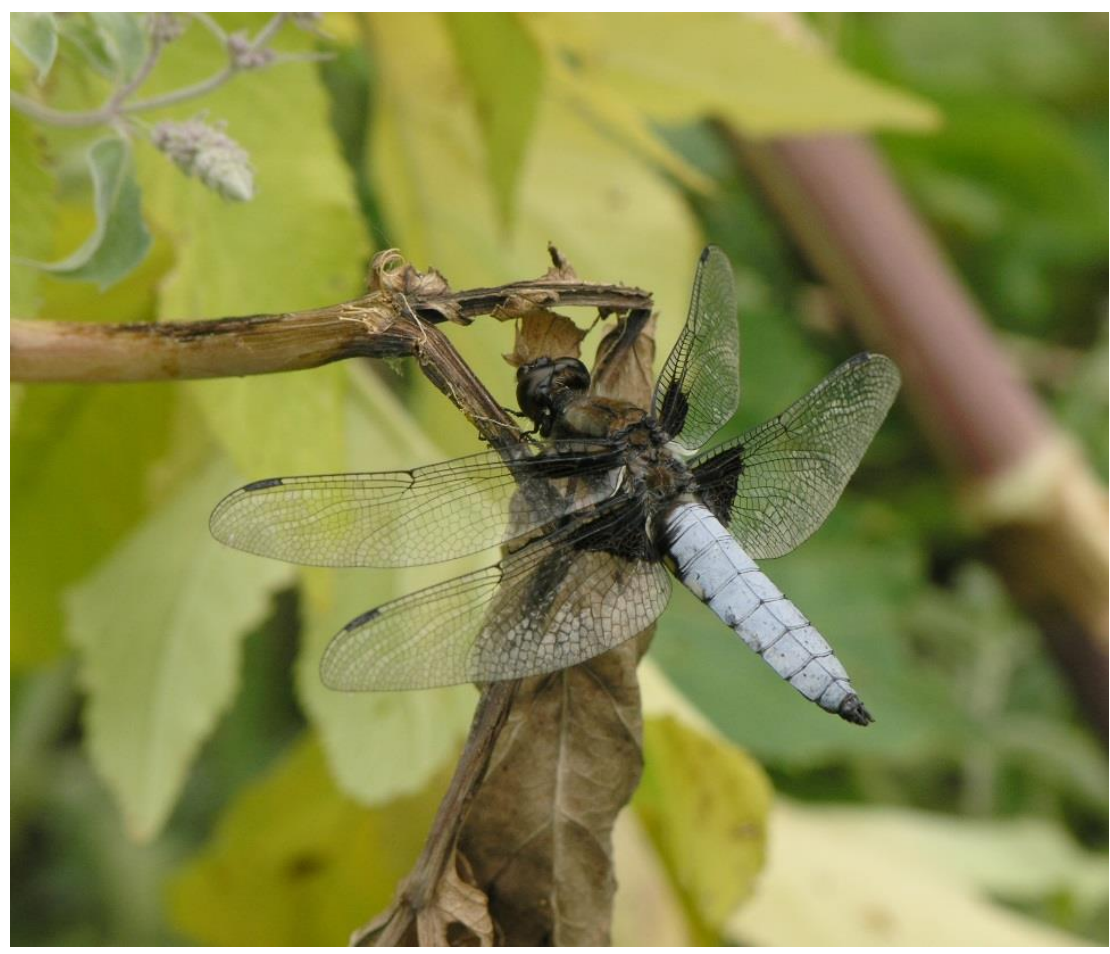

Fig. 1. A male of Libellula depressa at a bank of the Irtysh River left arm in Ust-Kamenogorsk (Oskemen), East Kazakhstan, $49.930^{\circ} \mathrm{N}, 82.663^{\circ} \mathrm{E}, 25.07 .2010$; photo by O.E. Kosterin.

Although the border of Russia and Kazakhstan is not associated with any natural object and resulted solely from the political history, the common sense of the toponym 'Siberia' refers to the territory of Russia; 
hence, until present $L$. depressa was formally unknown in Siberia. However, its presence in Kazakhstan near the border made its discovery in Siberia just a matter of time.

On $26^{\text {th }}$ of July 2009, the second author photographed a male of L. depressa (Fig. 2) at the Inya River (Fig. 3) in Chinetinskiy Zakaznik (a partially protected territory) $5-6 \mathrm{~km} \mathrm{~N}$ of Chineta Village (ca $51.38^{\circ} \mathrm{N}, 83.04^{\circ} \mathrm{E}$ ) in Krasnoshchekovo District of Altayskiy Kray Province, Russia.

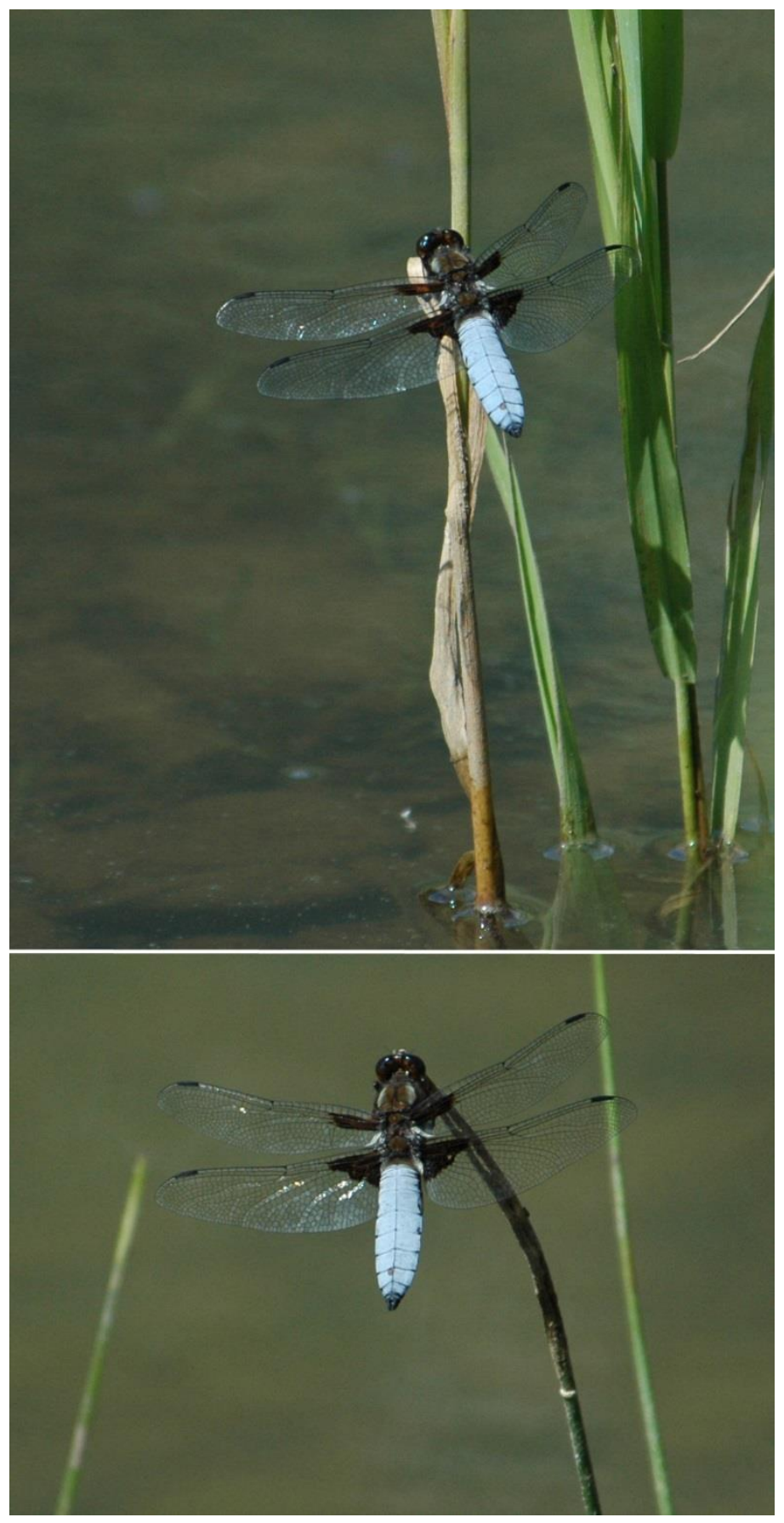

Fig. 2. A male of Libellula depressa at the Inya River in the vicinity of Chineta Village, Krashoshchekovskiy District, Altaiskiy Kray, Russia, 26.07.2010; photo by A.V. Gribkov

The Inya River (the Charysh River left tributary) flows in the north westernmost foothills of Altai Mountains at the elevation of $360 \mathrm{~m}$ a.s.l., in a valley bordered by the northern spurs of the Tigiretskiy Mountain Range elevating for 500-600 m above it. The habitat (Fig. 3) is rather typical for L. depressa elsewhere, although the species is quite eurytopic. This locality is $35 \mathrm{~km} \mathrm{NNW}$ of the Kazakhstan border and $150 \mathrm{~km}$ NNE of the closest known Kazakhstan locality of L. depressa in Ust-Kamenogorsk.

We need to mention that lower picture from Fig. 1 has been previously published in Atlas of Specially Protected Natural Territories of Siberian Federal District (Kalikhman et al., 2015: 153) as associated with a wrong place (Neninskiy Zakaznik) in Altayskiy Kray. 
Hence, L. depressa should be considered as species registered in Siberia and we can definitely expect its further records in Altayskiy Kray. In recent decades, many insect species including Odonata have been expanding their range northwards, at least in Europe, allegedly because of the ongoing global warming (Ott, 2010).

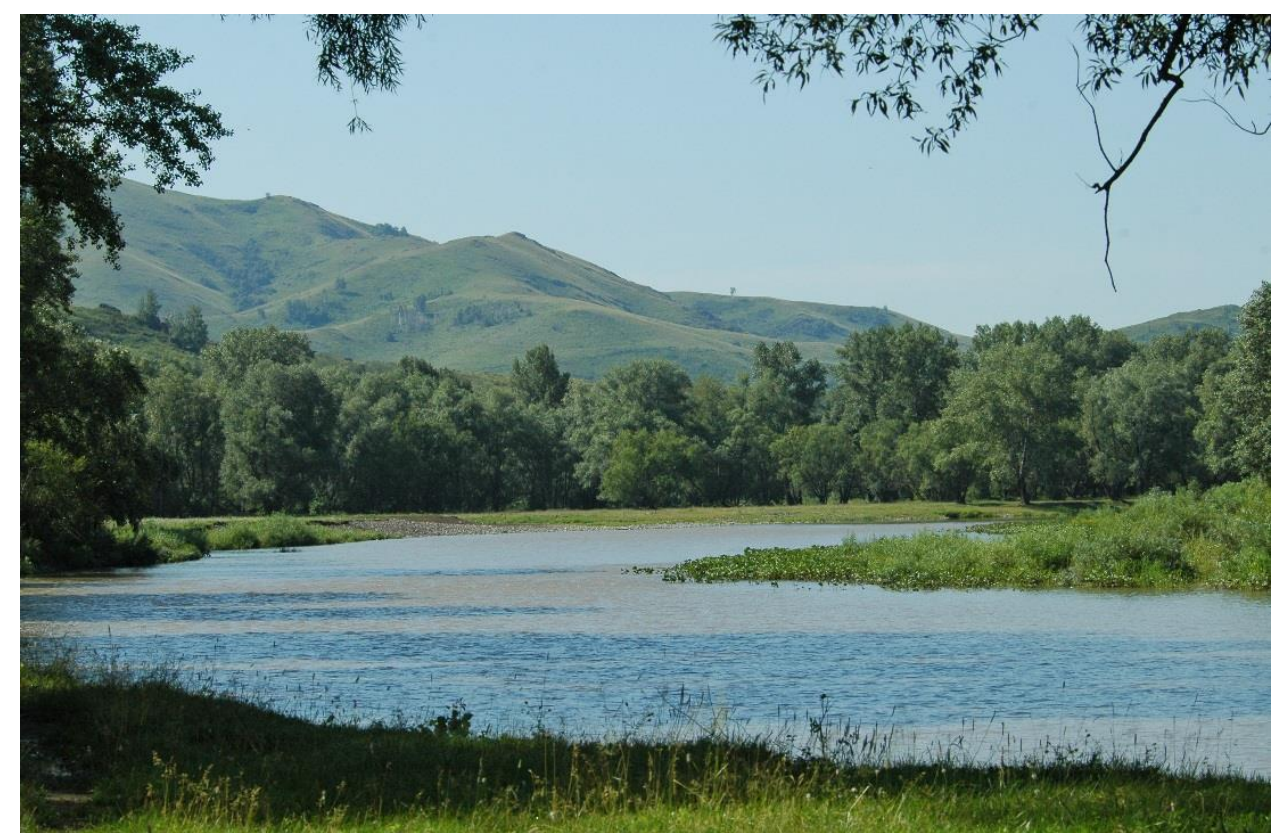

Fig. 3. The Inya River in the vicinity of Chineta Village (Krashoshchekovskiy District, Altayskiy Kray, Russia), a habitat of L. depressa, 26.07.2010; photo by A.V. Gribkov

For the last half century in Great Britain, this very species, L. depressa, has extended northwards for ca $100 \mathrm{~km}$ (Hickling et al., 2005). A similar process is taking place in some arthropods in West Siberia at least it was reported for representatives of spiders, catydids and mantises (one species of each) (Stolbov et al., 2016). At present it cannot be judged if $L$. depressa recently penetrated to Altayskiy Kray from Kazakhstan or that province was (and is) just underexplored. The answer can be obtained through further long-term monitoring of occurrence of the species in Altayskiy Kray.

\section{Acknowledgements}

The work of the first author was partly supported by International Dragonfly Fund and Russian State Scientific Project 0324-2019-0041.

\section{References}

Belyshev, B.F. (1973). Dragonflies (Odonata) of Siberia. Vol. 1. Part 2. Nauka, Siberian Division, Novosibirsk (in Russian).

Chaplina, I.A., Dumont, H.J., Haritonov, A.Y., Popova, O.N. (2007). A review of the Odonata of Kazakhstan. Odonatologica, 36(4), 349-364.

Hickling, R., Roy, Hill, J.K., Thomas, C.D. (2005). A northward shift of range margins in British Odonata. Global Change Biology, 11, 502-506.

Kalikhman, T.P., Bogdanov, V.N., Ogorodnikova, L.Y. (2012) Osobo okhranyaemye prirodnye territorii Sibirskogo Federal'nogo Okruga. Atlas [Specially Protected Nature Territories of Siberian Federal District. Atlas]. Ottisk, Irkutsk (in Russian).

Kalkman, V.J. \& Chelmick, D. (2015). Libel/ula depressa Linnaeus, 1758. Pp. 267-269. In: Boudot, J.-P. \& Kalkman, V.J. (eds). Atlas of the European Dragonflies and Damselflies. KNNNV Publishing, the Netherlands.

Ott, J. (2010) Dragonflies and climatic change - recent trends in Germany and Europe. BioRisk, 5, 253-286.

Stolbov. V.A., Kuzmin, I.V., Ivanov, S.A., Kamp, J. (2016) Expansion of the arthropod areals in Tyumenskaya and Kurganskaya Oblast's of West Siberia, Russia. Euroasian Entomological Journal, 15(2), 99-103.

\section{Citation:}

Kosterin, O.E., Gribkov, A.V. The first record of Libellula depressa Linnaeus, 1758 (Odonata: Libellulidae) in Siberia, Russia. Acta Biologica Sibirica, 5 (2), 30-32.

Submitted: 10.04.2019. Accepted: 19.06.2019

cross ref http://dx.doi.org/10.14258/abs.v5.i2.5928 